\title{
Term Limits and the Increased Election of Women: Evidence From State Legislatures and the U.S. House of Representatives
}

\author{
Stanley M. Caress and Todd Kunioka
}

\begin{abstract}
This study seeks to determine if term limits increase the likelihood of women being elected to legislative seats. Using a simple comparison of growth rates, we found that, during the initial period of term limit implementation (1991 to 2009), the increase of females elected to state legislatures with term limits was approximately the same as to those without term limits. Additionally, a comparison of the growth rate of females elected to the non-term-limited United States House of Representatives with those of the state legislatures during this same time period shows that the U.S. House actually had a greater increase than state legislatures both with and without term limits. Moreover, in California, which has a full-time, professional state legislature with electoral dynamics similar to the U.S. House, the proportion of women elected to the state's non-term limited U.S. House delegation from 1990 to 2009 exceeded the proportion of women elected to its term-limited state legislature. These comparisons all suggest that term limits do not facilitate the election of female candidates to legislative seats.
\end{abstract}

Term limits were originally promoted as a method to increase the responsiveness of elected officials, but some also speculated term limits could increase the number of women elected to legislative seats (Darcy, Welch, and Clark 1994). This increase in opportunity for women candidates was presumed to occur because term limits would remove one of the major barriers to legislative turnover: the high reelection rates of incumbents who seek reelection. Prior to term limit enactment, incumbent legislators were overwhelmingly male and tended to consistently seek and win reelection, thus acting as a barrier to aspiring female candidates. Since term limits would create numerous new open seats, they could conceivably open new opportunities for female candidates who would no longer need to challenge formidable incumbents (Nixon and Darcy 1996). The potential benefits to female and minority office-seekers were frequently cited by term limit supporters in their arguments in favor of term limit adoption (Jacobs 1991).

Term limits were initially adopted in 1990 by voter propositions in three states: California, Oklahoma, and Colorado. They continued to prove popular with the voters and 21 states eventually imposed them on their state legislatures, nearly all through the citizen initiative process. Six states, however, have since removed them by various legal means (National Conference of State Legislatures 2009).

STANLEY M. CARESS is a professor of political science at the University of West Georgia. TODD KUNIOKA is a former assistant professor at the California State University Los Angeles.

The American Review of Politics, Vol. 30, Fall, 2009: 275-287

(c)2009 The American Review of Politics 
Increased opportunities for female candidates created by term limits actually began in 1996, when the first cohort of state legislators in California and Maine were rotated out of office (Caress 1996; Katches and Weintraub 1997). Consequently, enough elections have now passed that it is possible to evaluate the assertion that term limits can improve the electoral fortunes of female legislative candidates. This study, by examining the gender composition of state legislatures and the U. S. House of Representatives, will measure the degree to which women have been successful in increasing their numbers; it will also assess whether the increase has been greater in those states with term limits.

\section{Early Projections of the Effect of Term Limits on Female Candidates}

An early study to determine the influence of legislative term limits on female candidates hypothesized that term limits could expand the electoral opportunities for women because they would remove the major impediment to the elections of female candidates-male incumbency (Thompson and Moncrief 1993). This study contended that without term limits the number of women elected would not increase even if the number of women office seekers increased because male incumbents would continuously run for reelection and block their path. This assumption was supported by examining the improved performance of female candidates in past races for open seats. The authors concluded that term limits, by increasing the number of open seats (mostly held by male incumbents), could substantially increase the number of women serving in legislatures.

Reed and Schansberg (1995) also considered the influence of term limits on the electoral success of female office seekers. They constructed a simulation model utilizing past congressional rates of continuation in office to project the opportunity potential for women under both a maximum of three and six terms in office. Their model, by using group-specific continuation rates, suggested that term limits tend to benefit groups that exit Congress the fastest. Since female incumbents stayed in office for shorter time periods than their male colleagues (11.9 versus 13.8 years), their model predicted the proportion of women in Congress would increase with term restrictions. They concluded that under a three-term limit the representation of women in Congress would increase steadily, and that a six-term limit would have a similar effect, but to a lesser degree.

Another study contended that term limits' greatest influence would be on legislative leadership (Hodson et al. 1995). This observation has a clear implication for women who successfully obtain office. It suggests that under term limitation there will be a far more rapid turnover of leadership positions, thus creating more leadership opportunities for women. If this notion 
is correct, it indicates that female incumbents would advance into leadership roles much sooner than they would in the absence of term limits.

One of the initial empirical studies of the influence of term limits on state legislatures using data from actual term-limited legislatures, found that there was a national trend of more women being elected to state legislatures from 1980 to 1996, but that during the period of term limit adoption [19911996], the rate of increase was virtually the same in states both with and without term limits (Caress 1998). The impact of reapportionment, which affects all states regardless of term limits, was found to be almost equivalent to that of term limits.

More recent research cast additional doubt on the likelihood that term limits have a positive effect on the number of women elected to office. Carey, Niemi, and Powell (2000) found that women were somewhat more likely to be elected to state legislatures that had term limits, but they did not believe term limits were the cause. Their interview data suggested that factors such as pay and length of legislative session played a greater role in explaining the under representation of women in state legislatures. Further, their statistical analysis suggested that traits of the legislative district were more important than term limits in explaining the success of female candidates. They found that legislative districts with smaller populations, located in states outside of the former Confederacy, and with Democratic Party traits (larger minority populations, higher proportions of college educated voters, and smaller proportions of people employed in the agricultural sector) were more likely to elect women.

A study that focused on the term-limited state legislatures in Michigan and California found an initial increase of women elected during and immediately after term limit imposition, followed by a leveling off at approximately 30 percent in California and the mid 20 percent range in Michigan (Sarbaugh-Thompson et al. 2004). While this study suggested an initial advantage for female candidates created by term limits, an earlier, more comprehensive study of national election trends in states both with and without term limits supported the observation that term limits made no difference in the growth rate of women elected to state legislatures (Carroll 2001). Similarly, an examination of election results from term limited states showed no clear pattern of women being more likely to win seats held by term limited legislators than those held by incumbents who were free to run for reelection (Carroll and Jenkins 2001). A later study focusing on California, however, found a similar increase in the election of female state legislators, but with most of the newly elected female legislators replacing term-limited incumbents, even though it wasn't clear if term limits were a contributing factor or just a co-occurrence (Cain and Kousser 2004). 
Also complicating any effort to assess the impact of term limits on the election of female candidates is the possibility of an anticipatory effect. This effect is created when incumbent legislators realize that their tenure in office is limited and voluntarily leave their seat before the mandatory retirement date to pursue other career options. This anticipatory behavior suggests that term limits can potentially influence electoral outcomes well before they create a complete, forced rotation of incumbents. Early studies found some evidence that the passage of term limits encouraged incumbents to retire before their forced retirement date to seek other career opportunities (Caress 1996; Carey, Niemi and Powell 2000). Cain and Kousser (2004) found additional evidence that term limit enactment created an anticipatory effect where incumbents left office before the completion of their allowable terms in office to seek other positions Additionally, Caress (1996) and Cain and Kousser (2004) noted an increase in special elections in some states that adopted term limits to fill inter-term vacancies created by incumbent legislators leaving office before their mandatory retirement date. This research, therefore, suggests that term limits can impact a legislative body even before their full implementation.

The evidence, therefore, on the impact of term limits on the growth of women elected to legislative seats remains inconclusive. While many studies found that the adoption of term limits coincided with an increase in women winning seats to state legislatures, they also tend to suggest that the relationship was not necessarily causal. Some studies suggest that the influence of term limits is minimal by showing that the proportion of women in state legislatures that did not impose term limits increased at a similar pace to those that did impose term limits. Further, in some term limited states, female representation increased initially, but soon reached a plateau, with the proportion of women in state legislatures stubbornly stuck in the range of 30 percent or below, depending on the state. Additionally, the potential existence of an anticipatory effect complicates efforts to determine the impact of term limits on the electoral fortunes of female legislative candidates. Thus, while there have been numerous studies on the impact of term limits and the election of women, there is still a need for additional clarifying research.

\section{Methodology}

Analysis is divided into three sections. First, a simple comparison is conducted of trends in the percentage of women elected to state legislative office from states that have term limits with the percentage of women elected to state legislatures from states that do not have term limits (Tables 1 and 2). In Table 1, we define a state as having term limits solely by consider- 
Table 1. State Legislature Membership: Percent Female

\begin{tabular}{ccc}
\hline Year & $\begin{array}{c}\text { States With } \\
\text { Term Limits in 2009 }\end{array}$ & $\begin{array}{c}\text { States Without } \\
\text { Term Limits in 2009 }\end{array}$ \\
\hline 1979 & $9.5 \%$ & $10.0 \%$ \\
1981 & $11.5 \%$ & $11.8 \%$ \\
1983 & $12.9 \%$ & $13.2 \%$ \\
1985 & $14.2 \%$ & $14.5 \%$ \\
1987 & $16.4 \%$ & $15.0 \%$ \\
1989 & $17.2 \%$ & $16.7 \%$ \\
1991 & $18.8 \%$ & $17.9 \%$ \\
1993 & $21.2 \%$ & $20.0 \%$ \\
1995 & $21.9 \%$ & $20.2 \%$ \\
1997 & $23.4 \%$ & $20.7 \%$ \\
2009 & $23.5 \%$ & $21.9 \%$ \\
2003 & $23.5 \%$ & $22.0 \%$ \\
2005 & $22.7 \%$ & $22.3 \%$ \\
2007 & $23.5 \%$ & $22.3 \%$ \\
2009 & $22.8 \%$ & $23.2 \%$ \\
\hline
\end{tabular}

T-scores for difference in means test did not approach traditional levels of significance for any of the years above.

Table 2. Percent of State Legislators Who Are Women in States with Term Limits-Forced Rotation of All Incumbents

\begin{tabular}{ccc}
\hline & $\begin{array}{c}\text { States With Entire } \\
\text { Legislative Membership } \\
\text { Rotated Out of Office (n) }\end{array}$ & $\begin{array}{c}\text { States Without Entire } \\
\text { Legislative Membership } \\
\text { Rotated Out of Office (n) }\end{array}$ \\
\hline 1997 & $24.2 \%(2)$ & $21.4 \%(48)$ \\
1999 & $26.2 \%(6)$ & $21.9 \%(44)$ \\
2001 & $25.4 \%(12)$ & $21.6 \%(38)$ \\
2003 & $24.1 \%(11)$ & $21.9 \%(39)$ \\
2005 & $23.1 \%(12)$ & $22.5 \%(38)$ \\
2007 & $22.8 \%(14)$ & $23.4 \%(36)$ \\
2009 & $23.8 \%(14)$ & $24.2 \%(36)$ \\
T-scores for difference in means test does not achieve statistical significance for any of the periods \\
listed above.
\end{tabular}


ing if state legislators were, in 2009, subject to term limitations. In Table 2, we define a state as "having term limits" only if all incumbents in at least one of the state's legislative chambers have already been forced out of office and are unable to seek reelection. This method examines the possibility that term limit enactment can affect a legislature's composition even prior to mandatory forced retirement, and thus takes into account any anticipatory effect. Defining states as "having term limits" both ways allows us to check for any anticipatory legislator behavior, in addition to seeing if states that passed term limits differed systematically from states that have not passed term limits in their propensity to elect women to state legislative office.

Second, data from the states are contrasted with the growth rate of female members in the United States House of Representatives from 1990 to 2009. This information, presented in Table 3, illustrates changes in the nonterm-limited U.S. House that occurred during the same time states were adopting and implementing term limit on their state legislative bodies. The growth rate of female representation in the U.S. House is then compared to those rates in states both with and without term limits.

Third, we compared the number of females in the term-limited state legislature in California with their level of representation in the state's

Table 3. Percentage Female Membership: Comparison of States With and Without Term Limits With the U.S. House of Representatives, 1990-2009

\begin{tabular}{lccc}
\hline & & $\begin{array}{c}\text { State Legislatures } \\
\text { With } \\
\text { Term Limits }\end{array}$ & $\begin{array}{c}\text { State Legislatures } \\
\text { Without } \\
\text { Term Limits }\end{array}$ \\
\hline 1991 & U.S. House & $18.8 \%$ & $17.9 \%$ \\
1993 & $6.4 \%$ & $21.2 \%$ & $20.0 \%$ \\
1995 & $10.8 \%$ & $21.9 \%$ & $20.2 \%$ \\
1997 & $11.0 \%$ & $23.4 \%$ & $20.7 \%$ \\
1999 & $12.4 \%$ & $23.5 \%$ & $21.9 \%$ \\
2001 & $12.9 \%$ & $23.5 \%$ & $21.9 \%$ \\
2003 & $13.6 \%$ & $22.7 \%$ & $22.3 \%$ \\
2005 & $13.8 \%$ & $23.5 \%$ & $23.2 \%$ \\
2007 & $15.6 \%$ & $22.8 \%$ & $24.2 \%$ \\
2009 & $16.6 \%$ & $23.8 \%$ & 6.3 \\
Percentage & $16.8 \%$ & 5.0 & \\
Point Increase & 10.4 & & \\
Percentage of female members of the U.S. House is calculated based upon information from CAWP, \\
2009.
\end{tabular}



Table 4. Gender Comparison: Women as a Percent of California's
State Legislature and California's Congressional Delegation

\begin{tabular}{ccc}
\hline & $\begin{array}{c}\text { California } \\
\text { State Legislature }\end{array}$ & $\begin{array}{c}\text { California's } \\
\text { U.S. House Delegation }\end{array}$ \\
\hline 1979 & $9.2 \%$ & $0.0 \%$ \\
1981 & $10.0 \%$ & $2.4 \%$ \\
1983 & $11.7 \%$ & $6.7 \%$ \\
1985 & $12.5 \%$ & $6.7 \%$ \\
1987 & $14.2 \%$ & $4.4 \%$ \\
1989 & $15.8 \%$ & $4.4 \%$ \\
1991 & $17.5 \%$ & $6.7 \%$ \\
1993 & $23.3 \%$ & $11.5 \%$ \\
1995 & $20.8 \%$ & $15.4 \%$ \\
1997 & $22.5 \%$ & $17.3 \%$ \\
1999 & $25.8 \%$ & $25 \%$ \\
2001 & $28.3 \%$ & $33.7 \%$ \\
2003 & $30.0 \%$ & $34.0 \%$ \\
2005 & $30.8 \%$ & $37.7 \%$ \\
2007 & $28.3 \%$ & $33.9 \%$ \\
2009 & $27.5 \%$ & $36.5 \% * *$
\end{tabular}

*As of August 1, 2009 there is one vacancy in California's congressional delegation. 19 of the remaining 52 seats were filled by women.

non-term-limited congressional delegation (Table 4). California provides an interesting natural experiment on the effects of term limits on the election of women to legislative office because of the similarity between its congressional and state legislative election dynamics. During the years under study, California had a delegation in the U. S. House of Representatives of between 42 (in 1979) and 53 (from 2001-2009) seats, while its lower state legislative chamber had 80 members and its upper chamber 40 members. This makes California the only state in the union where members of its U.S. House delegation represent smaller districts (geographically and based on population) than do members of one of its state legislative chambers. Also, the California state legislature ranks at or near the top on various measures of professionalization (pay, days in session, staff size) among the fifty states. Because of the relative size of the districts and the attractiveness of the office, the electoral dynamics for California state legislative races are quite similar to those of congressional elections. Thus, by comparing the growth rate of females elected to the term-limited state legislature in California with the increase in females elected to California's non-term-limited congressional 
delegation, we have a natural experiment testing the impact of term limits while holding all other factors constant.

Information on the status of term limits in the various states for each year under study is based upon information from the National Conference of State Legislatures. ${ }^{1}$ The information on women as a percentage of each state's legislature was retrieved from the Center for American Women in Politics at Rutgers University. ${ }^{2}$ Information on the gender breakdown of both California's state legislative and its federal congressional delegations was also gathered from the previously-noted Center for American Women in Politics.

\section{Findings}

\section{Similar Growth Rates Found in States Both With and Without Term Limits}

Table 1 compares the growth of the percentage of women in legislatures with term limits with growth in those without term limits. It shows that the percentage of women elected to state legislatures currently with term limits has not grown at a significantly different rate from legislatures without term limits. In both sets of states the proportion of females in the state legislatures increased substantially between 1979 and 2009. In some years, the states currently with term limits elected proportionately more women to their legislature, while in other years, states currently without term limits sent more women to the state capitol. In only one year, however, was the difference more than 2.5 percentage points, and in no cases did the t-score (not presented in these tables) exceed the level of confidence necessary to demonstrate statistical significance.

Table 1 also shows only weak evidence of an anticipatory effect. The proportion of women elected to state legislatures increased slightly sooner in states that adopted term limits than in states that did not. However, as previously noted, the difference was not statistically significant. Also, the cause of the earlier increase in the proportion of women elected to the state legislature cannot necessarily be credited to the passage of term limit legislation.

Table 2 illustrates that, even when comparisons are strictly limited to states with an "entire" forced-rotation of a chamber's members due to term limits, the proportion of females in state legislatures remains similar. While in the earliest years of term limits implementation there was a larger percentage of women elected to state legislatures with a complete rotation of incumbents, this advantage soon dissipated. The percentage of women in termlimited states under this definition increased only through 1999. As the number of states in this category increased, the number of female state 
legislators declined, while their numbers continued to increase in states without a complete incumbent rotation. Regardless, once again the difference between the two categories never approaches the levels of confidence required to achieve statistical significance, and thus the influence of term limits must be considered negligible.

\section{Congressional Female Growth Outpaces State Legislatures}

Several states that established term limits for their state legislatures also imposed limits on their congressional delegations. The U.S. Supreme Court in 1995, however, overturned state-imposed congressional term limits in U.S. Term Limits Inc. $v$ Thornton, ${ }^{3}$ which held that states could not dictate election qualifications for the federal legislative body, and that only Congress could determine its own election rules. While term limits have been introduced in the Congress a number of times, each attempt has failed: Congress has always been and remains an un-term-limited body.

During the time period when term limits were being implemented at the state level, the gender composition of United States House of Representatives also experienced an increase in the size of its female membership. After the 1990 election, when voters first passed legislative term limits in three states, the U.S. House's membership was 6.4 percent female (Table 3). By 1999, after the first cohort of state lawmakers in California and Maine were barred from reelection due to term limits, the number of female congressional members had risen to 12.9 percent. After the 2004 election, the percentage had increased to 15.6 percent. By 2009, 16.8 percent of the members in the U.S. House were women.

In contrast, after the 1990 election, women were 18.8 percent of the membership of legislatures in states with term limits and 17.9 percent in states without term limits. By 2009 these percentages had increased to 23.8 percent and 24.2 percent respectively. While the state percentages were larger than in the U.S. House, the pace of their growth was much slower. From 1990 to 2009 the female membership of the U.S. House increased 10.4 percentage points, which was nearly double the rate of increase in both states with term limits (five percentage points) and with non-term limited legislatures (6.3 percentage points). This larger increase in women elected to the U.S. House occurred without the forced rotation of incumbents that impacted the term-limited states legislatures. This suggests the general increase in women elected to legislative seats during this time was largely, if not completely, independent of the influence of term limits. 


\section{More Rapid Female Increase in California's Non-Term-Limited Congressional Delegation than in California's Term-Limited State Legislature}

While women have become increasingly successful in getting elected to the U.S. House of Representatives nationwide, the evidence from California is even more dramatic. Table 4 shows that in 1979, none of the 42 members of the U.S. House of Representatives sent from California were women. However, as of 2009, 36.5 percent of the state's delegation to the U.S. House is female. Since 2001, women have composed over one-third of California's U.S. House delegation. By contrast women have never filled so much as one-third of the seats in California's state legislature.

Ironically, while the increase in women elected to the California U.S. House delegation began well before the adoption of term limits in that state in 1990, it accelerated greatly during the time when California was imposing term limits on its state legislature (1990-1999). In the four elections following the passage of state legislative term limits in California, the state's U.S. House female contingent nearly quadrupled in relative size, from 6.7 percent of the delegation in 1991 to 25 percent of the delegation in 1999. As is the case with the rest of the U.S. House, this increase occurred without the imposition of term limits on the state's congressional delegation. This clearly indicates that the existence of term limits does not facilitate the election of women.

\section{Discussion}

There has been an undeniable trend of women being elected in increasing numbers to legislative seats during the past three decades. This is the case for state legislatures both with and without term limits, and it is also the case for the U.S. House of Representatives. The data provided in this study, however, indicate that term limits were not the cause of this increase. Since the growth rate of females elected in states with term limits is not statistically greater than in states without term limits, nor is it greater than in the non-term-limited U.S. House, it is safe to assert that term limits do not directly facilitate the election of female candidates. The comparison of election results between California's delegation to the U.S. House and its state legislative delegation reinforces this conclusion.

The growth of women elected to office in all states legislatures regardless of term limits contradicts some of the earlier, preliminary projections in the literature which suggested that term limits would have a markedly positive effect on female representation in state legislatures. It is, however, consistent with later studies of election data that compared the election of 
Table 5. The Status of Term Limits in the Fifty States

\begin{tabular}{|c|c|c|c|}
\hline $\begin{array}{l}\text { States With Legislative } \\
\text { Term Limits }\end{array}$ & \multicolumn{2}{|c|}{$\begin{array}{l}\text { States That Never Enacted } \\
\text { Term Limits }\end{array}$} & $\begin{array}{l}\text { States that Once } \\
\text { Had Term Limits, } \\
\text { But Repealed Them } \\
\text { (as of 2009) }\end{array}$ \\
\hline Arizona & Alabama & New Mexico & Idaho \\
\hline Arkansas & Alaska & New York & Massachusetts \\
\hline California & Connecticut & North Carolina & New Hampshire* \\
\hline Colorado & Delaware & North Dakota & Oregon \\
\hline Florida & Georgia & Pennsylvania & Utah \\
\hline Louisiana & Hawaii & Rhode Island & Washington \\
\hline Maine & Illinois & South Carolina & Wyoming \\
\hline Michigan & Indiana & Tennessee & \\
\hline Missouri & Iowa & Texas & \\
\hline Montana & Kansas & Vermont & \\
\hline Nebraska & Kentucky & Virginia & \\
\hline Nevada & Maryland & West Virginia & \\
\hline Ohio & Minnesota & Wisconsin & \\
\hline Oklahoma & Mississippi & & \\
\hline South Dakota & New Jersey & & \\
\hline
\end{tabular}

women in state legislatures in term limited versus non-term limited states. This study demonstrates that neither the actual forced rotation of incumbents, nor any anticipatory effect created by term limit enactment increases the electoral success of female candidates running for legislative seats.

Term limits are only one of several factors that might affect the gender composition of a legislative body. The broader literature suggests socioeconomic, cultural and other institutional factors may all play important roles in explaining the increased election of women to state legislatures. Female candidates have been more successful in winning legislative election in non-southern states, in states with larger minority populations, and in states where the electorate has attained higher educational levels (Carey, Niemi and Powell 2000). Historically, women have also had greater success winning seats when the state legislature is less professional, with shorter legislative sessions, smaller staffs, and lower compensation levels (Sanbonmatsu 2006; Carey Niemi and Powell 2000; Squire 1992; Hill 1981). There is also some evidence from international studies that utilizing multi-member electoral districts produces more female legislators than the single-member district system common in this country (Schwindt-Bayer 2005). 
Even though women have made significant inroads, state legislature and the U.S. House continue to be dominated by males. Nonetheless, the increase in gender equity in legislative representation should not be minimized and is an important trend in American politics. This study, however, indicates that term limitation does not appear to be a facilitating factor. Regardless, fifteen state legislatures have term limits on their state legislatures as of 2009 (Table 5). Future trends will need to be examined to see if this non-effect continues.

\section{NOTES}

${ }^{1}$ www.ncsl.org/Default.aspx?Tabld=1484. NCSL (National Conference of State Legislatures). 2009. “The Term Limited States.” Downloaded August 3, 2009.

${ }^{2}$ www.cawp.rutgers.edu. CAWP (Center for the American Woman and Politics, Rutgers University). 2009. "Women in the U.S. Congress 1917-2009.” Downloaded August 5, 2009.

${ }^{3}$ U.S. Term Limits Inc. v Thornton, 1995. (93-1456) (514 U.S. 779).

\section{REFERENCES}

Cain, Bruce, and Thad Koussnar. 2004. Adapting to Term Limits: Recent Experiences and New Directions, Public Policy Institute of California Report.

Caress, Stanley M. 1996. The Impact of Term Limits on Legislative Behavior: An Examination of a Transitional Legislature. PS: Political Science and Politics 29:671-677.

Caress, Stanley M. 1998. The Influence of Term Limits on the Election of Women. Women and Politics 20:45-63.

Carey, John M., Richard G. Niemi, and Lynda W. Powell. 2000. Term Limits in the State Legislatures. Ann Arbor: University of Michigan Press.

Carroll, Susan J. 2001. The Impact of Term Limits on Women. Spectrum: The Journal of State Government 74:19-21.

Carroll, Susan J., and Krista Jenkins. 2001. Do Term Limits Help Women Get Elected? Social Science Quarterly 82(1):197-201.

Darcy, R., Susan Welch, and Janet Clark. 1994. Women, Elections, and Representation, 2nd ed. Lincoln: University of Nebraska Press.

Hill, David B. 1981. Political Culture and Female Political Representation. Journal of Politics 43:159-168.

Hodson, Timothy, Rich Jones, Karl Kurtz, and Gary Moncrief. 1995. Leaders and Limits: Changing Patterns of State Legislative Leadership Under Term Limits. Spectrum: The Journal of State Government 68:6-16.

Jacobs, Paul. 1991. Term Limits in America. Washington, DC: Cato Press.

Katches, Mark, and Daniel M. Weintraub. 1997. The Tremors of Term Limits. State Legislatures 23:20-25.

National Conference of State Legislatures. 2009. The Term Limited States. www.ncsl.org/ Default.aspx?Tabld=1484. Downloaded August 3, 2009. 
Nixon, David L., and R. Darcy. 1996. Special Elections and the Growth of Women's Representation in the U.S. House of Representatives. Women \& Politics 16:99.

Reed, W. Robert, and D. Eric Schansberg. 1995. The House under Term Limits: What Would It Look Like? Social Science Quarterly 76:698-719.

Sanbonmatsu, Kira. 2006. Where Women Run: Gender and Party in the American States. Ann Arbor: University of Michigan Press.

Sarbaugh-Thompson, Marjorie, Lyke Thompsom, Charles D. Elder, John Strate, and Richard C. Elling. 2004. The Political and Institutional Effects of Term Limits. New York: Palgrave/Macmillian.

Schwindt-Bayer, Leslie A. 2005. The incumbency disadvantage and women's election to legislative office. Electoral Studies 24:227-244.

Squire, Peverill. 1992. Legislative Professionalization and Membership Diversity in State Legislatures. Legislative Studies Quarterly 17(1):69-79.

Thompson, Joel A., and Gary F. Moncrief. 1993. The Implications of Term Limits for Women and Minorities: Some Evidence from the States. Social Science Quarterly 74:300-309. 